\title{
Clericalism Contributes to Religious, Spiritual, and Behavioral Struggles among Catholic Priests
}

\author{
Thomas G. Plante ${ }^{1,2}$ \\ 1 Department of Psychology, Santa Clara University, 500 El Camino Real, Santa Clara, CA 95053, USA; \\ tplante@scu.edu \\ 2 School of Medicine, Stanford University, 291 Campus Drive, Stanford, CA 94305, USA
}

Received: 16 March 2020; Accepted: 20 April 2020; Published: 28 April 2020

\begin{abstract}
The Roman Catholic Church has received a remarkable amount of press attention regarding clerical perpetrated sexual abuse with child victims as well as other clerical behavioral scandals in recent years. Much has been reported in both the popular and professional press about the various aspects and elements of priestly formation and ministry that might contribute to behavioral problems among clerics. Additionally, much has also been written and discussed about the challenging religious, spiritual, and behavioral struggles among clerics when clerical misbehavior significantly contradicts expected behavior in terms of sexual, behavioral, and relational ethics. Since Catholic priests are dedicated to chastity, obedience, and, among religious order clerics, poverty, both Catholics and non-Catholics alike expect and demand highly virtuous behavior from these men that they believe should be beyond reproach. Clericalism contributes to the gap between expected and actual behavior and creates an environment and culture where problem behavior and struggles are too often ignored. This article seeks to unpack some of the challenging dynamics of clericalism and demonstrate how it negatively contributes to religious, spiritual, moral, and behavioral struggles among Catholic clerics.
\end{abstract}

Keywords: Catholic; clericalism; priests; clerics; sexuality

Child sexual abuse perpetrated by Roman Catholic priests has been headline news for almost two decades when the story exploded in January 2002 with published reports in the Boston Globe (Boston Globe Investigative Staff 2002). Press attention from other outlets quickly followed and the story of sexual abuse of minor children by celibate Catholic priests and the cover up of these behaviors by Church leaders (e.g., bishops) was an outrage to the general public as well as to rank and file Catholics. The enormous impact of the Boston Globe's reporting was made into a highly popular motion picture entitled Spotlight, that ultimately won an academy award for best picture in 2015. Although the longstanding and chronic problem of sexual abuse of children by Catholic clerics had been well known since at least the 1980s (Berry 2000; Plante 1999b; Sipe 1995), the issue did not really enter into the minds of the general public until the 2002 Boston Globe investigative reports were published. The story of clerical abuse in the church was later determined to be a more global problem, with similar stories reported from Ireland, Australia, Chile, and elsewhere creating a global church crisis (Plante and McChesney 2011). In more recent years, the sexual exploitation of young adult seminarians and other non-clerical laypersons (e.g., church congregants, church employees, and religious sisters) by Catholic priests has received a great deal of attention as well.

Many professionals, as well as the general public, have wondered and speculated about the various factors that might contribute to clerical misbehavior when their standards for behavior are so high (e.g., Frawley-O'Dea 2007; Manuel 2012; McGlone and Sperry 2012; Wilson 2008). They have wondered about the role of an all-male clergy, their commitment to chastity, and the hierarchical structure of the Catholic Church as examples (Frawley-O'Dea 2007). Clericalism has also been frequently mentioned as an important risk factor for clerical struggles and misbehavior (Cozzens 2000; Manuel 2012; Plante 
2019). The purpose of this article is to discuss the role of clericalism in the Church and how it contributes to religious, spiritual, moral, and behavioral struggles among Catholic clerics.

\section{Defining Clericalism}

What exactly is clericalism? Clericalism may be found in many organizations beyond religious or spiritual ones and is the tendency to allow a small group of highly regarded and special leaders to have the power and privilege to make all or most of the important and critical decisions for the organization and those within it (Doyle 2003; Wilson 2008). These decisions are usually made without any significant input from those within or outside of the institution. While these special leaders might welcome input or speak of collaboration, it is expressed primarily for good public relations or optics and is not necessarily sincere (Doyle 2003; Frawley-O'Dea 2007; Wilson 2008). In the Roman Catholic faith tradition, clericalism manifests itself with the belief and practice that only ordained clergy, such as priests and bishops, have any true authority to make decisions and can do so without input from non-priests or non-bishops (Cozzens 2000). These decisions involve Church matters about liturgy, sacraments, Church programs and finances but also about intimate day-to-day decisions about very personal and family matters such as sexual expression and intimate relationships (Wilson 2008). Thus, in the Roman Catholic Church, those who are allowed and are privileged to wear the Roman collar, signifying their clerical state, position, and power, make all of the important decisions, maintaining final authority on a variety of very diverse issues and concerns related to Church functioning (Doyle 2003). In addition, they also have authority about how Church members should behave and even think and believe in private. Clericalism underscores the belief and practice that priests and bishops are very special, superior to laypeople in matters personal and religious, and that their authority and pronouncements on all issues should be accepted and acted upon without input by those without the clerical designation. Often, these clerical practices are acted upon without open-minded consultation from non-clerics or from those not within the insular inner circle of special clerical decision makers (Cozzens 2000; Doyle 2003; Wilson 2008).

Roman Catholic priests and bishops are not alone in their susceptibility to clericalism broadly defined. Clericalism may be found among clerics from all religious and spiritual traditions whenever power and control are strictly concentrated among an inner group of special leaders (e.g., Sanneh 1976). Thus, rabbis, pastors, imams, gurus, and so forth all are vulnerable to clericalism dynamics. Furthermore, the dynamics of this style of power and control can be found in non-religious or non-spiritual professions such as in medicine, law, the military, government, and educational institutions as well. Whenever you have an inner group of highly elevated leaders who either put themselves or are placed by others onto an elevated pedestal, a misuse of power and control can potential occur (e.g., Luebke 1963). Signs of a clerical culture also can be observed when power is concentrated among one or just a few very special people who often enjoy unique privileges, and typically have special and honorary titles and clothing (Wilson 2008). The problems of concentrated power and control can penetrate most any hierarchical institution or organization, either secular or religious. Moreover, when this approach is considered blessed by the divine having God's approval, it can be even more problematic and resistant to change, debate, or to correct (Doyle 2003; Frawley-O'Dea 2007; Wilson 2008).

\section{Clericalism Is a Problem for the Church}

Clericalism can be highly destructive for clerics, laypersons, and their affiliated communities and institutions. It is dangerous because it does not allow for productive checks and balances as well as input and feedback that is vital to develop and maintain best practices and thoughtful quality decision making in any institution (Doyle 2003; Frawley-O'Dea 2007; Wilson 2008). It minimizes and often simply prevents diverse perspectives and multiple voices from the many stakeholders and with various skill sets to have an important, welcomed, and respected voice in the important matters facing the community or organization. In the Roman Catholic Church, the vast majority of Church members, which includes all women, married persons, and all lay experts in multiple and relevant 
fields (e.g., business, finance, real estate, medicine, psychology, law enforcement, youth protection), are routinely excluded from the critical reflection and decision making process (Benkert and Doyle 2009). Curiously, this even includes religious and theological scholars and experts with much more academic and sometimes practical experience than priests and bishops, if they happen to be either woman or laypersons (Wilson 2008; Zagano 2011). Clerics in clerical cultures often tend to believe and embrace that they are in fact quite special and infallible in their religious and non-religious beliefs, behaviors, and practices relative to others (Frawley-O'Dea 2007). Clericalism supports the possibility and nurturance of narcissism (Furnham et al. 2013; Zondag 2006). In fact, in the words of Pope Francis during a presentation delivered in Dublin, Ireland on 25 August 2018: “ ... The abuse of power exists. Who among us does not know an authoritarian bishop? Forever in the church, there have been authoritarian bishops and religious superiors. And authoritarianism is clericalism."

\section{Clericalism Is a Problem for Clerics Too}

How might clericalism be a problem for clerics since it seems to provide them with nothing but advantages? Being a powerful decision maker with few checks and balances may be appealing to some. Yet, upon closer inspection, it should become clear that clericalism is actually dangerous and an insidious problem for clerics themselves. All of that specialness has many important negative implications. For example, when clerics struggle with common human challenges and feelings such as loneliness, problematic alcohol or drug abuse, overeating, mood or behavioral disorders and dysfunction, they may feel confused and unable to get the very help that they need (Doyle 2003; Manuel 2012; Plante 1999b, 2004, 2015, 2019). They may wonder that if they are so special and important, how they could possibly have such common human problems that might lead to significant religious and spiritual struggles and questioning of their identity and life path (Manuel 2012). Furthermore, since the Church has extremely high expectations when it comes to sexual behavior and even sexual impulses, clerics are especially unable to admit to both others and even themselves that they need help (Manuel 2012; Plante and McChesney 2011; Plante 2015; Wilson 2008). For example, Catholic clerics are expected to be celibate and avoid any sexual contact with anyone including both adult men and women, and are not allowed to masturbate (Manuel 2012). They are asked to channel their sexual drives into non-sexual pursuits and are expected to be perfect in these endeavors. This is destined for failure as well as both moral and spiritual crises. If clerics feel that they cannot admit to any sexual concerns or challenges, they are likely to avoid potentially helpful interventions and consultations. The odds of small problems becoming bigger ones become more probable (Manuel 2012).

Researchers have examined various dimensions of religious and spiritual struggles and have identified six different and independent dimensions of these problems (i.e., divine, demonic, interpersonal, moral, doubt, and meaning) that can be assessed by a recently developed questionnaire entitled, the Religious and Spiritual Struggles Scale (Exline et al. 2014). Certainly, clerics dealing with the unintended consequences and down sides of clericalism can easily struggle with moral and interpersonal challenges that might contribute to problems with meaning making, doubt, and result in acting out behaviors too (Cozzens 2000; Manuel 2012; Plante and McChesney 2011). Yet, as of this date, there does not appear to be any available and published comprehensive research using this scale with a large-scale Catholic cleric research population.

\section{Humans Frequently Struggle with Their Impulses and Behavior, Sexual and Otherwise}

Part of the human condition for many is an ongoing struggle with their impulses and behavior. For example, in most cultures, communities have high expectations for sexual behavior for everyone (e.g., Tillman et al. 2019). Pre-marital sex, marital infidelity, homosexuality, pornography use, and so forth are commonly discouraged and sometimes considered illegal. Tragically, engaging in these common sexual behaviors can be reason for imprisonment and even state sponsored execution in some cultures (e.g., Clemens 2005). Yet, many people have personal experiences with these issues and for many they are an ongoing and often stressful challenge. Frequently, people find themselves, 
intentional or not, in highly destructive and both emotionally and physically harmful relational situations. They may shamefully engage in behaviors that violate their own expectations for relational behavior, morals, and religious beliefs (e.g., Fahs et al. 2018). Certainly, these issues result in religious and spiritual challenges and crises when the offender is a member of the clergy and their behavior and conflicts directly conflict with their religious and spiritual identities (Frawley-O'Dea 2007; Manuel 2012). For example, marital affairs, pornography use and abuse, sexual assaults, engaging sex workers, and child sexual victimization are all too common and likely have been so for centuries. Specifically, $20 \%$ of American college females claim that they have been sexually assaulted while on campus according to a 2014 White House Task Force on college sexual assault (White House Task Force to Protect Students from Sexual Assault 2014). Additional research informs us that that approximately $30 \%$ of females and about $15 \%$ of men in the United States state that they were sexually victimized by an adult while they were a minor child (American Psychological Association 2014; United States Department of Justice 2019). Pornography is a highly profitable multibillion dollar a year business and sex trafficking that exploits vulnerable women and young girls is a chronic and serious global problem (e.g., Eberstadt and Layden 2010). Sexual identity issues are a concern for many and those who have homosexual orientations have been oppressed, marginalized, and persecuted for millennium (e.g., Burks 2011; Rivers and D'Augelli 2001). Even in current more enlightened times, homosexuality is a crime in many global locations, and in some communities, it is punishable by death (e.g., Forbes 2017). Thus, people are often challenged by their impulses and in particular their sexual expression and identity.

Roman Catholic priests (including bishops, cardinals, and the Pope) are dedicated celibates. They not only are forbidden from being married or partnered but they are not allowed to engage in any sexual expression at all, including masturbation. Priestly ordination certainly does not change the fact that priests are still human with the full range of human desires and needs, including sexual ones. Clericalism elevates the expectations of the cleric, and those around him, to suggest that he is not truly human and is perhaps in more of a perfected or elevated state (Frawley-O'Dea 2007). This then severely hampers the reality of the fully human person and thus, encourages the repression and denial of sexual and other urges and desires without a healthy and productive path towards integration (Cozzens 2000, 2006; Manuel 2012).

\section{A Unique Religious and Spiritual Struggle: Clericalism Prevents Clerics from Embracing Their Humanity}

For Catholic priests, problems with any emotional, sexual, psychological, or behavioral functioning are further challenged and compromised by clericalism in that these human difficulties and concerns are so often simply never discussed, understood, supported, or confronted within an open, health promoting, non-judgmental, and productive environment (Manuel 2012). Thus, conflict emerges with one's calling to serve God and the faith community, yet still struggling with human emotions, feelings, and behaviors that make these religious and spiritual challenges unique for Catholic clerics with a commitment to celibacy. Clericalism ultimately encourages denial and repression, and if a cleric cannot or will not discuss their conflicts and behavior with a trusted peer, confessor, spiritual director, or religious superior, these issues then typically become more challenging and destructive over time (Manuel 2012; Plante and McChesney 2011). Too often clerics try to manage their psychological and behavioral concerns completely alone or perhaps within their very small circle of trusted colleagues without seeking help from knowledgeable experts either within or outside of their Church community. Without openness and support, initial problems can easily grow into much bigger and serious problems. Some try to cope with their challenging impulses and behaviors though prayer alone, which may be inadequate. Thus, clericalism encourages denial of typical human challenges and often the avoidance of possible helpful strategies for effective coping and managing these human issues. 


\section{Typical Problems Associated with Clericalism and Sexuality}

Typical problems that Catholic clerics encounter with clericalism and sexuality in particular include difficulties with chronic and compulsive pornography use, compulsive masturbation, and sexual acting out most typically with either consenting adults or paid sex workers (Manuel 2012; McGlone and Sperry 2012; Plante 1999a, 2004, 2013, 2019; Plante and McChesney 2011; Thoburn and Baker 2011). Often their forbidden need for sexual expression and release, their needs for intimacy, affirmation, connection, and their struggles with loneliness intersect and unfold in ways that more destructive coping strategies are chosen and then acted upon (Frawley-O'Dea 2007). Clericalism frequently results in an unwillingness to seek professional help as well as an increased probability of using denial and repressive defenses in an attempt to try to maintain the more perfect and idealized clerical persona (e.g., Plante and Aldridge 2005; Plante et al. 1996). Their psychological and emotional defenses then likely deteriorate when their problematic behaviors get them into trouble when, for example, they are arrested for sexual solicitation or are caught in a police sting. Alternatively, perhaps they are caught with a sexual partner or viewing pornography on their computers. Additionally, if they are caught with child pornography or sexually engaging with youth under the age of 18 then law enforcement becomes involved, arrests and convictions occur, the media reports on the scandal and hypocrisy of the church, and life-long consequences for multiple parties unfold. This certainly adds to their troubles including religious, spiritual, and moral ones as well.

Psychological consultation is typically sorely needed and can help with conducting a root cause analysis of the cleric's behavior, diagnoses, co-morbid psychological and other problems such as alcohol and substance abuse, chronic depression, anxiety, or personality dysfunction. Mental health professionals can also help develop a treatment, wellness, and safety plan moving forward (Plante 1999a, 2004; Plante and McChesney 2011; Thoburn and Baker 2011). Additionally, professional psychological consultation can assist a local religious superior, such as a bishop or religious order provincial, in determining what type and level of supports are available for the cleric as well as how to manage their behavioral risks for the future. Many bishops and provincials are now using psychological services to support their clerics, but this is decided upon by individual religious superiors and is not universal in implementation (Congregation for Catholic Education 2008; Plante 2019).

\section{Guiding Principles in Working with Catholic Seminarians and Clerics}

There are several helpful guiding principles that can assist clergy in dealing with the psychological and behavioral problems often associated with clericalism. These principles can be used effectively to better help clerics manage their impulses and behavior in healthy and affirming ways.

\subsection{Embrace and Never Deny One's Humanity}

Clericalism should be confronted in such a way that helps clerics to never forget that, regardless of their clerical state and privilege, they are always fully human and thus, experience the full range of human emotions and challenges, for good and for bad. These human emotions certainly include sexual ones but all others too, including religious doubts and "spiritual dryness" (Baumann et al. 2019). Clerical ordination certainly cannot eliminate one's impulse and desires. The challenging issue for clerics is how to best manage these feelings and behaviors in a healthy, productive, and safe manner that is consistent with religious promises and behavioral expectations, while still honoring their very human existence, experiences, and desires. Humans, clerics or not, can expect to have emotional, behavioral, spiritual, and relational struggles throughout life.

\subsection{Anticipate That Human Impulsesand a Deep Desire for Intimacy Will Be Part of One's Entire Life Experience}

Even married laypeople throughout the course of their marriage will be challenged by their sexual and relational impulses, desires, and fantasies that may tempt them to betray their marital promises. 
In addition, clerics, being fully and completely human, can expect to be tempted to make compromises regarding their religious promises as well. For example, finding other people sexually and romantically compelling is natural and can be expected throughout the lifespan. They may have religious doubts and concerns that trouble them as well. Acknowledging the important realities and preparing for healthy ways to deal with them are critically needed for all clerics and laypersons alike.

\subsection{Find Healthy and Frequent Opportunities to Remove the Roman Collar}

Problems associated with clericalism can be confronted with frequent opportunities to remove the Roman collar, both literally and figuratively, and engage in healthy productive activities as a person and not mainly being identified as a cleric. Joining a recreational athletic team or fitness club can be a healthy way to enjoy and engage with others in a realistic and non-clerical manner. Taking an exercise, cooking, art or other hobbyist class, for example, may be highly rewarding as well. Avoiding wearing clerical attire while doing non-clerical activities such as grocery shopping, attending a musical, dramatic, or sporting event, and during other non-Church related activities also provides a rich and frequent opportunity to remind oneself of one's ordinary yet fully humanness. The point of these suggestions is to engage in regular activities and with people as a fellow human being without being in the role of being a cleric inviting others to treat one with special status (Coleman 2006; Cozzens 2006; Manuel 2012).

7.4. Maintain a Supportive Group of People to Nurture Close and Intimate Relationships and Opportunities for Open Conversations about the Challenges of Being a Cleric

Years of quality, research supports the notion that social support is remarkably important for wellness and healthy adaptive human functioning (e.g., Leigh-Hunt et al. 2017). Clerics can very easily find themselves surrounded only by fellow clerics with little if any support from a larger and more diverse group of people. Maintaining close and supportive relationships with a wide range of friends, relatives, and supportive others, both clerics and non-clerics, is critically important to nurture healthy interpersonal intimacy and safe venues for discussing the many challenges of living a celibate clerical life with minimum clericalism (Coleman 2006; Cozzens 2006; Manuel 2012).

\section{Conclusions}

Priests are people too. This might seem like an obvious statement but clericalism tempts people, especially clerics and their congregants, to think otherwise (Coleman 2006; Cozzens 2000, 2006; Manuel 2012). Clericalism reinforces that ordained clerics in the Catholic Church are unique, special, and closer to God than non-clerics. Clerics promise not to marry or have any sexual relationships or experiences with anyone, and even masturbation and pornography use are forbidden. Clerics often maintain or project an idealized image that they are always in a spiritual and godly state and do not suffer from the human difficulties, including those associated with human desires and expression. Their special status, attire, and role in the Church encourages and reinforces clericalism while the faithful often passively go along and support this notion of divine specialness among the ordained. Typically, laypersons are encouraged to treat clerics with a great deal of respect, deference, and even awe.

While it may be flattering and reinforcing to have people treat you with deference and reverence, it is actually dangerous to allow it to happen in an ongoing and unchecked manner and may encourage narcissism (Manuel 2012; Frawley-O'Dea 2007). Again, in the words of Pope Francis in an address to the Chilean Bishops (18 May 2018): "An elite or elitist psychology ends up generating dynamics of division, separation and closed circles that lead to narcissistic and authoritarian spiritualties in which, instead of evangelizing, the important thing is to feel special, different than others, thus making it clear that they are interested in neither Jesus Christ or others." Priests who struggle with typical and expected human difficulties, including spiritual, religious, and moral ones, may feel too embarrassed or even paralyzed to reach out for personal or professional help. Their sexuality and sexual impulses, for example, may then form and develop in unhealthy and unproductive directions that include the 
use of pornography, engaging paid sex workers, and seeking illicit sexual encounters with adults and even minors. These destructive behaviors are usually a sign of problematic and unhealthy approaches to dealing with loneliness and a need for intimacy, distraction, validation, connection, and stress management (Coleman 2006; Cozzens 2000, 2006; Manuel 2012). Being mindful of these very human challenges and nurturing a more seamless and trusting collegial relationship with experts, such as mental health professionals who specialize in religious and spiritual matters and can work effectively with clerics, go a long way towards better helping seminarians and clerics alike manage the challenges of being fully human. Clericalism gets in the way of supporting clerics to live whole, complete, and healthy lives. The Church, clerics, and the laity all can do their part to push back and find strategies to combat clericalism for the good of the Church, the clerics, and for everyone.

Funding: This research received no external funding.

Conflicts of Interest: The authors declare no conflict of interest.

\section{References}

American Psychological Association. 2014. Child Sexual Abuse: What Parents Should Know. Washington: American Psychological Association, Available online: http://www.apa.org/pi/families/resources/child-sexual-abuse. aspx (accessed on 1 April 2020).

Baumann, Klaus, Eckhard Frick, Christoph Jacobs, and Arndt Büssing. 2019. Spiritual Dryness and Celibacy in Catholic Priests-Discernment of Ongoing Spiritual Journeys from Relational and Psychosexual Immaturities. Pastoral Psychology 68: 605-17. [CrossRef]

Benkert, Marianne, and Thomas P. Doyle. 2009. Clericalism, religious duress and its psychological impact on victims of clergy sexual abuse. Pastoral Psychology 58: 223-38. [CrossRef]

Berry, J. 2000. Lead Us Not into Temptation: Catholic Priests and the Sexual Abuse of Children. Champaign-Urbana: University of Illinois Press.

Boston Globe Investigative Staff. 2002. Betrayal: The Crisis in the Catholic Church. New York: Little Brown.

Burks, Derek J. 2011. Lesbian, gay, and bisexual victimization in the military: An unintended consequence of “Don't Ask, Don't Tell"? American Psychologist 66: 604. [CrossRef]

Clemens, Aaron M. 2005. Executing homosexuality: Removing anti-gay bias from capital trials. Georgetown Journal Gender \& Law 6: 71.

Coleman, Gerald D. 2006. Catholic Priesthood: Formation and Development. Ligurori: Ligurori.

Congregation for Catholic Education. 2008. Guidelines for the Use of Psychology in the Admission and Formation of Candidates for the Priesthood. Vatican City: The Vatican Congregation for Catholic Education.

Cozzens, Donald B. 2000. The Changing Face of the Priesthood: A Reflection on the Priest's Crisis of Soul. Collegeville: Liturgical Press.

Cozzens, Donald. 2006. Freeing Celibacy. Collegeville: Liturgical Press.

Doyle, Thomas P. 2003. Roman Catholic clericalism, religious duress, and clergy sexual abuse. Pastoral Psychology 51: 189-231. [CrossRef]

Eberstadt, Mary, and Mary Anne Layden. 2010. The Social Costs of Pornography. Princeton: The Witherspoon Institute.

Exline, Julie J., Kenneth I. Pargament, Joshua B. Grubbs, and Ann Marie Yali. 2014. The Religious and Spiritual Struggles Scale: Development and initial validation. Psychology of Religion and Spirituality 6: 208. [CrossRef]

Fahs, Breanne, Eric Swank, and Sara I. McClelland. 2018. Sexuality, pleasure, power, and danger: Points of tension, contradiction, and conflict. In APA Handbooks in Psychology. APA Handbook of the Psychology of Women: History, Theory, and Battlegrounds. Edited by Cheryl B. Travis, Jacquelyn W. White, Alexandra Rutherford, Wendi S. Williams, Sarah L. Cook and Karen Fraser Wyche. Washington: American Psychological Association, pp. 229-47.

Forbes, Simon. 2017. The reconstruction of homosexuality and its consequences in contemporary Iran. The SOAS Journal of Postgraduate Research 10: 25-47.

Frawley-O'Dea, Mary Gail. 2007. Perversion of Power: Sexual Abuse in the Catholic Church. Nashville: Vanderbilt University Press. 
Furnham, Adrian, Steven C. Richards, and Delroy L. Paulhus. 2013. The Dark Triad of personality: A 10 year review. Social and Personality Psychology Compass 7: 199-216. [CrossRef]

Leigh-Hunt, Nicholas, David Bagguley, Kristin Bash, V. Turner, S. Turnbull, Nicole K Valtorta, and Woody Caan. 2017. An overview of systematic reviews on the public health consequences of social isolation and loneliness. Public Health 152: 157-71. [CrossRef] [PubMed]

Luebke, Fred C. 1963. The Origins of Thomas Jefferson's Anti-Clericalism. Church History 32: 344-56. [CrossRef] Manuel, Gerdenio S. 2012. Living Celibacy: Healthy Pathways for Priests. Mahwah: Paulist Press.

McGlone, Gerard J., and Len Sperry. 2012. The Inner Life of Priests. Collegeville: Liturgical Press.

Plante, Thomas G., ed. 1999b. Bless Me Father for I Have Sinned: Perspectives on Sexual Abuse Committed by Roman Catholic Priests. Westport: Praeger/Greenwood.

Plante, Thomas G. 1999a. A collaborative relationship between professional psychology and the Roman Catholic Church: A case example and suggested principles for success. Professional Psychology: Research and Practice 30: 541-46. [CrossRef]

Plante, Thomas G., ed. 2004. Sin against the Innocents: Sexual Abuse by Priests and the Role of the Catholic Church. Westport: Praeger/Greenwood.

Plante, Thomas G. 2013. A call for life long spiritual and psychological formation of priests. Human Development 34: 30-34.

Plante, Thomas G. 2015. Six principles to consider when working with Roman Catholic clients. Spirituality in Clinical Practice 2: 233-37. [CrossRef]

Plante, Thomas G. 2019. Consultation with religious professionals and institutions. In Consultation in Health Service Psychology: Advancing Professional Practice-A Competency-Based Approach. Edited by Carol A. Falender and Edward P. Shafranske. Washington: American Psychological Association.

Plante, Thomas G., and Arianna Aldridge. 2005. Psychological patterns among Roman Catholic clergy accused of sexual misconduct. Pastoral Psychology 54: 73-80. [CrossRef]

Plante, Thomas G., and Kathleen L. McChesney, eds. 2011. Sexual Abuse in the Catholic Church: A Decade of Crisis, 2002-2012. Santa Barbara: Praeger/ABC-CLIO.

Plante, Thomas G., Gerdenio Manuel, and Curtis Bryant. 1996. Personality and cognitive functioning among sexual offending Roman Catholic Priests. Pastoral Psychology 45: 129-39. [CrossRef]

Rivers, Ian, and Anthony R. D'Augelli. 2001. The victimization of lesbian, gay, and bisexual youths. Lesbian, Gay, and Bisexual Identities and Youth: Psychological Perspectives 9: 187-210.

Sanneh, Lamin. 1976. The origins of clericalism in West African Islam. The Journal of African History 17: 49-72. [CrossRef]

Sipe, A. W. Richard. 1995. Sex, Priests, and Power: Anatomy of a Crisis. New York: Brunner Mazel.

Thoburn, John, and Rob Baker, eds. 2011. Clergy Sexual Misconduct: A Systems Approach to Prevention, Intervention, and Oversight. Carefree: Gentle Path Press.

Tillman, Kathryn Harker, Karin L. Brewster, and Giuseppina Valle Holway. 2019. Sexual and Romantic Relationships in Young Adulthood. Annual Review of Sociology 45: 133-53. [CrossRef]

United States Department of Justice. 2019. Facts and Statistics: Raising Awareness about Sexual Abuse; Washington: United States Conference of Catholic Bishops. Available online: https://www.nsopw.gov/(X(1)S(5yp1dtw1s2p1d5mqmmapyblg))/en-US/Education/FactsStatistics? AspxAutoDetectCookieSupport=1 (accessed on 1 April 2020).

White House Task Force to Protect Students from Sexual Assault. 2014. Not alone: The First Report of the White House Task Force to Protect Students from Sexual Assault. Washington: The White House.

Wilson, George B. 2008. Clericalism: The Death of Priesthood. Collegeville: Liturgical Press.

Zagano, Phyllis. 2011. Women \& Catholicism: Gender, Communion, and Authority. Berlin: Springer.

Zondag, Hessel J. 2006. Narcissism and motivation for the pastorate. Journal of Empirical Theology 19: 227-43. [CrossRef]

(C) 2020 by the author. Licensee MDPI, Basel, Switzerland. This article is an open access article distributed under the terms and conditions of the Creative Commons Attribution (CC BY) license (http://creativecommons.org/licenses/by/4.0/). 